\title{
Distribution of Capelin (Mallotus villosus) in Relation to Coastal Upwelling in the Avalon Channel
}

\author{
David C. Schneider \\ Ocean Sciences Centre, Memorial University of Newfoundland \\ St. John's, Newfoundland, Canada A1B 3X7
}

\begin{abstract}
Three hypotheses were developed from a series of studies of capelin (Mallotus villosus) distribution in the southern Labrador Current. The hypotheses were that: (1) water mass replacement due to coastal upwelling occurs at the spatial scale predicted by the balance between buoyant and Coriolis forces; (2) upwelling generates a cross-shore gradient in capelin abundance; and (3) this gradient decays after an episode of upwelling favorable winds. An initial experiment, reported elsewhere, confirmed these predictions for a single strong episode of upwelling favorable winds ending 2 July 1987. To determine whether these predictions hold for typical upwelling events, closer to the average strength, the experiment was repeated during the period of high capelin abundance (mid-June to mid-July) over a 3 year period. The first hypothesis, of wind driven water mass replacement, was confirmed in 29 out of 30 cases where a test was possible. The average lateral extent of cold water near the coast was $5 \mathrm{~km}$ as predicted. A gradient in capelin abundance (higher abundance near the coast) was observed at this scale in 13 out of 15 instances, confirming the second hypothesis. The gradient changed in response to upwelling during the strong event in early July of 1987, and in another event during mid-July of 1988. On average, however, the gradient changed in the expected direction in only 2 out of 7 instances where a test was possible. Repeated observational experiments showed that capelin respond to strong upwelling events (sea surface temperature less than $2^{\circ} \mathrm{C}$ ) but do not respond to more typical events.
\end{abstract}

Key words: Capelin, distribution, Labrador Current, Northwest Atlantic, upwelling

\section{Introduction}

Coastal upwelling is a familiar physical process with well studied effects on nutrient distribution and primary production. The effects of coastal upwelling on the movements and distribution of larger animals have received less investigation, perhaps because the relevant time scales are short, being set as much by the velocities of actively swimming animals as by the velocity of the water itself. One simple mechanism linking the distribution and movements of nektonic organisms to coastal upwelling is the response of stenothermal species to physically driven displacements of isotherms (Sleggs, 1933; Templeman, 1948).

The distribution and movements of capelin (Mallotus villosus) have been linked to upwelling along the eastern coast of Newfoundland (Buzdalin and Burmakin, 1976; Piatt and Methven, 1986; Schneider and Piatt, 1986; Piatt, 1987; Schneider and Methven, 1988). Based on these results three specific hypotheses were developed and tested during a strong wind event (Schneider, 1989). The hypotheses were that: (1) water mass replacement occurs at the spatial scale predicted by the balance between buoyant and Coriolis forces; (2) upwelling generates a cross-shore gradient in capelin abundance; and (3) this gradient decays after an episode of upwelling favorable winds. All three predictions were confirmed for a single episode of upwelling favorable winds ending 2 July 1987 (Schneider, 1989). Continuous profiling of seasurface temperature (SST) along experimental transects revealed cold water at the sea surface within $6 \mathrm{~km}$ of the coast, similar to the $5 \mathrm{~km}$ value predicted from the first internal Rossby radius calculated from wind, latitude and vertical density gradient. This seaward gradient in SST disappeared 2 days after the wind event. Acoustic profiles from the same transect showed traces of schooling fish near the sea surface within $7 \mathrm{~km}$ of the coast, becoming less intense seaward. These traces became more dispersed the following day, and were virtually absent 3 days after the wind event. Spectral analysis of presence-absence data extracted from the echogram showed relatively high spectral density on 2 and 3 July at spatial scales greater than $2 \mathrm{~km}$, then a flat spectrum on 4 July. 
These results were obtained during an extremely strong upwelling event, so it was of interest to investigate whether similar responses occur during more typical events. It was also of interest to determine whether changes in distribution occur during the spin-up stage of upwelling, as well as during the relaxation stages. The present study reports the results of repeated testing of hypotheses (1) (2) and (3) at the same site in the southern Labrador Current.

\section{Methods}

Transects were run on successive mornings immediately after a wind event that was vigorous enough, in theory, to raise the thermocline to the surface (typically 2 days of 20 to 25 knot winds from the southwest, cf. Schneider and Methven, 1988). Experimental transects were also run on successive mornings in anticipation of such events, based on forecasts for this area by the Atmosphere and Environment Service (AES at Gander). During 1987 a triangular spatial design was used to test the longshore repeatability of results on two adjacent transects. The triangular route ran east-southeast from the dock at Bay Bulls (point A in Fig. 1) to the entrance of this bay (point B in Fig. 1). This was labelled transect $A_{e}$. The triangular route then continued southeast to a point $12 \mathrm{~km}$ from the coast. This segment running eastward from point B in Fig. 1 was labelled transect $B_{e}$. The distance from shore at the end of this transect was measured with radar. The route turned westward toward Gull Island (point D in Fig. 1). This segment was labelled transect $C$. The route then ran northward to the entrance of Bay Bulls (point E in Fig. 1). This segment was labelled transect $D$. The return into Bay Bulls, closely paralleling transect $A$, was labelled transect E. During 1988 this was shortened to a linear design to test repeatability along the same transect. The linear route ran east-southeast from the dock to the entrance of the Bay (transect $A_{e}$ ), southeast $12 \mathrm{~km}$ (transect $B_{e}$ ), then northwest back to the bay (transect $B_{W}$ ), returning to the dock (transect $A_{W}$ ). During 1988 the triangular design was run once (12 July). During 1989 both the triangular and the linear design were used (Fig. 1). Ship velocity along each transect was calculated from time and distance between point positions recorded at the start and end of each transect.

Six experiments (two per year) were completed during the period of high capelin abundance (ca. 15 June through 10 July) in the Avalon Channel in

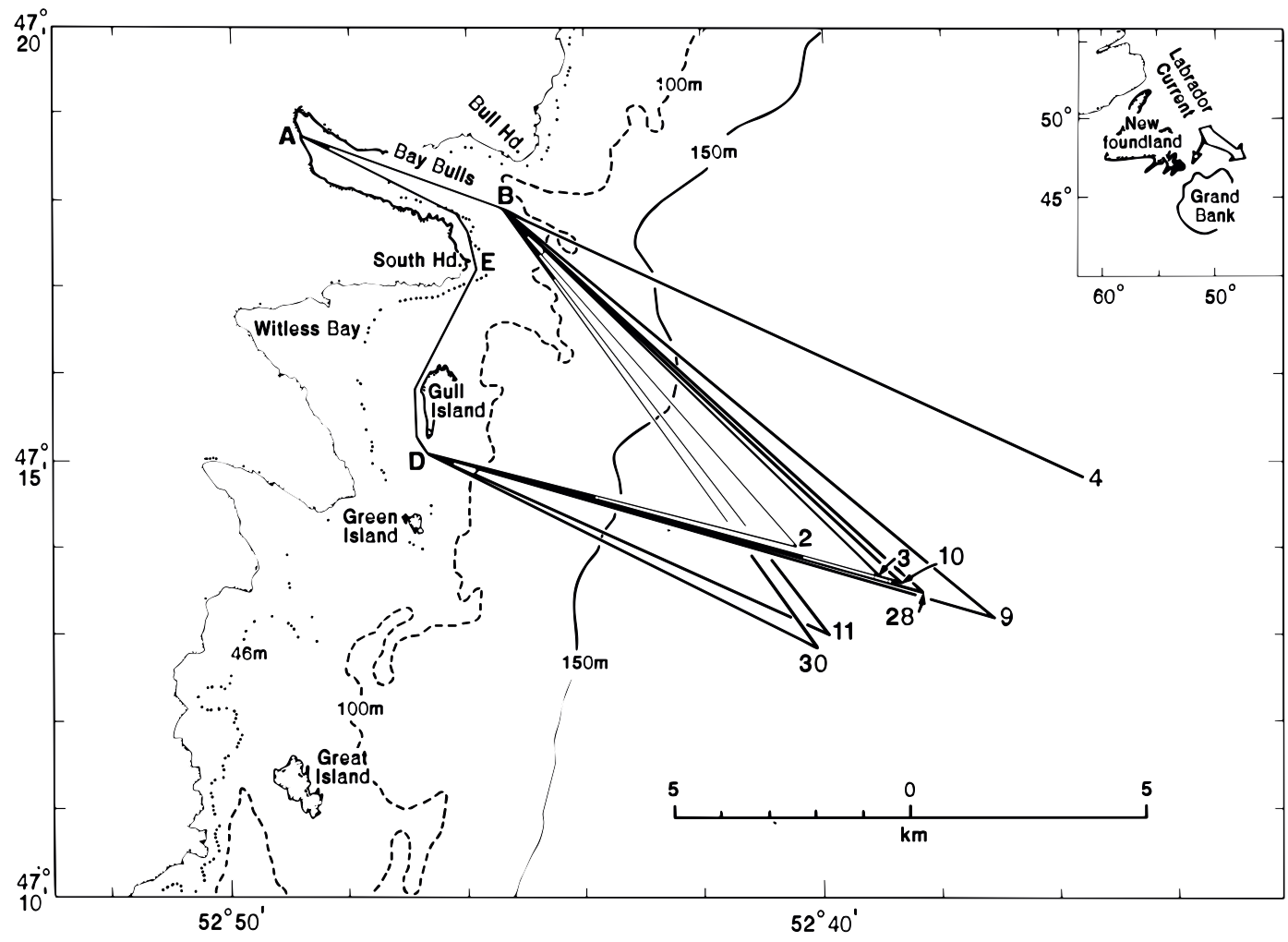

Fig. 1. Location of transects across the inshore arm of the Labrador Current in 1989. 
1987, 1988 and 1989. A seventh experiment was completed in late July 1987, after the period of high capelin abundance. All surveys were begun at first light in the morning. Ship velocities were on the order of $200 \mathrm{~m} \mathrm{~min}^{-1}$.

A towed thermistor was used to record SST $\left({ }^{\circ} \mathrm{C}\right)$ at 1 min intervals in 1987, 5 minute intervals in 1988, and 1 min intervals in 1989. Echograms were obtained with a depth sounder mounted on the vessel hull in 1987, and an echosounder mounted on a pipe bolted to the ship 1988 and 1989. Paper tapes of the $50 \mathrm{kHz}$ echogram were marked in 1-min intervals laterally, and $10 \mathrm{~m}$ depth intervals vertically. Traces characteristic of capelin were initially judged (Criterion 1) as any dark trace below the surface, using the same criterion as that of Piatt and Methven (1986). Interpretations of paper tapes were checked with one of these authors (DAM) to make sure that they were consistent with earlier work at this site. Traces were marked as present or absent in each square on each tape.

Previous work at this site (Piatt and Methven, 1986) interpreted multiple contiguous traces as schooling fish (Piatt and Methven, 1986; Schneider and Piatt, 1986). During 1988 a video camera was towed on a V-fin depressor at a depth of $2 \mathrm{~m}$, looking forward beneath the hull from approximately $4 \mathrm{~m}$ behind the stern, to confirm whether these traces were capelin. The camera record showed that multiple dark traces used in previous studies were schooling fish, which were visible as a sudden flash of relatively even spaced animals swimming rapidly. When a single video image was held on the screen, these flashes were clearly fish, but the resoIution of the camera was insufficient to detect more detail in the stopped images. Contiguous dark traces characteristic of schooling fish were observed on transects made through flocks of alcids (Common Murres Uria aalge and Atlantic Puffins Fratercula arctica). Alcids in these flocks brought capelin (and only capelin) to the surface, confirming that the contiguous dark traces in the study area were schooling capelin. Contiguous traces extending below the surface, often with horizontal bends, were clearly capelin and so were scored and recorded separately (Criterion 2) from all dark traces (Criterion 1).

Spatial gradients were calculated at the scale of the first internal Rossby radius $(5 \mathrm{~km})$ for capelin abundance, defined as $N=$ number of 1 min segments with dark contiguous traces. The gradients were calculated as $\mathrm{N}_{\text {in }}-\mathrm{N}_{\text {out }}$, and hence was positive if there were more occurrences within $5 \mathrm{~km}$ of shore $\left(N_{\text {in }}\right)$ than beyond $\left(N_{\text {out }}\right)$. The sign of the gradient (+ or - ) was used to test hypotheses 2 and 3 .
The gradient in abundance, calculated in this fashion, is subject to the contaminating effects of smaller scale gradients. Thus, an apparently positive gradient at the scale of $5 \mathrm{~km}$ may in fact be due to a concentration of capelin occurrent within $1 \mathrm{~km}$ of the coast. To control for this, the spatial variance in abundance was estimated with spectral techniques, which estimate variance at a sequence of measurement frequencies, with variance at other frequencies removed. Calculations were made with the BMDP package (Dixon, 1983). The package estimates spatial variance $V(F)$ as a function of measurement frequency $\left(F=\right.$ cycles $\left.\min ^{-1}\right)$, and expresses this as spectral density $\left(V_{F}=V(F) /\right.$ $F)$. Spectral density was estimated with triangular smoothing windows of $0.05,0.1,0.2$, and $0.4 \mathrm{cy}-$ cles min $^{-1}$. A smoothing window between 0.1 and 0.2 was judged to give the best compromise between high detail at narrow windows (e.g., 0.05 cycles $\mathrm{min}^{-1}$ ) and smoothness of plot at wide windows. As these results showed the best window to be between 0.1 and 0.2 cycles/min, the process was repeated using smoothing windows of $0.12,0.14$, and 0.16 cycles $\mathrm{min}^{-1}$. A smoothing window of $0.15 \mathrm{cy}-$ cles $\mathrm{min}^{-1}$ was judged to give the best compromise between detail and smoothness across all analyses. The smoothing window nearest to 0.15 cycles min $^{-1}$ was used in each analysis. Spectral density was then graphed in the distance domain $(D=\mathrm{km}$ cycle ${ }^{-1}$ ) using average speed $v_{i}$ along each transect to calculate $D_{i}=F^{-1} v_{i}$. This allowed direct comparison of plots from transects differing in spatial resolution and length. The analytical method differs only slightly from that of Schneider (1989). Hypotheses 2 and 3 were tested by scoring plots of spectral density according to whether large scale variance $\left(V_{D<.5 / \mathrm{km}}\right)$ exceeded smaller scale variance $\left(V_{D>.5 / \mathrm{km}}\right)$. Hypothesis testing was based on the difference between large and small scale variance, scored as a binomial variable ( + and - ) and hence makes no assumption about the distribution of the data or residuals. The procedure uses spectral smoothing techniques to estimate variance as a function of measurement frequency, but does not use the standard parametric tests of significance often used in spectral analysis.

\section{Results}

\section{Upwelling hypothesis}

Because of the uncertainty of the weather at periods of 2-3 days into the future, not all experiments were completed exactly as anticipated. Figure 2 shows an example of the observed changes in wind direction and speed, calculated from records at Torbay airport, in units of specific kinetic energy $\left(E=\mathrm{km}^{2} \mathrm{hr}^{-2}\right)$. Experiment 87I, in early July, developed as anticipated, with continued low winds, permitting measurement of SST and capelin 


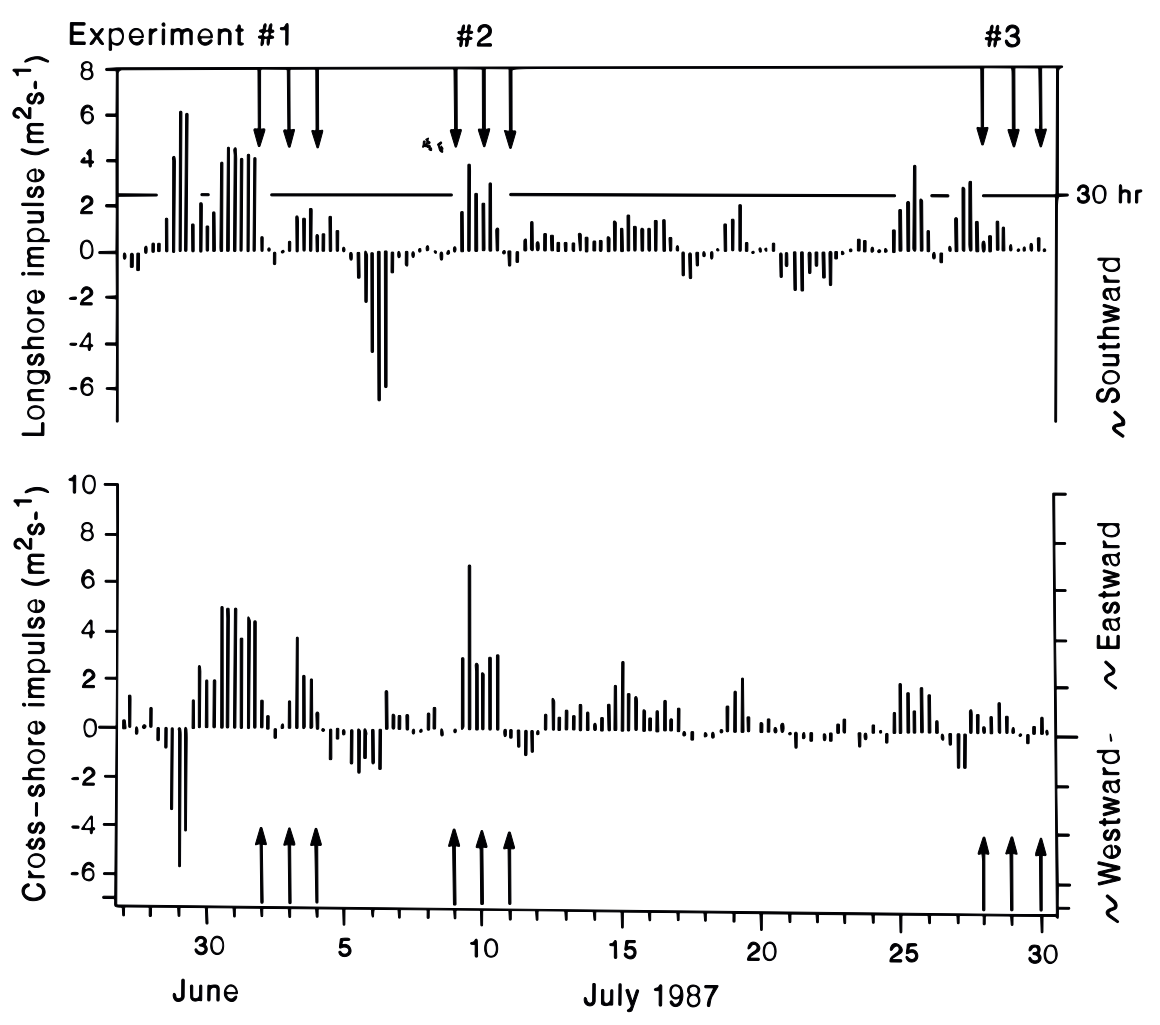

Fig. 2. Dates of experiments $87 \mathrm{I}, 87 \mathrm{II}$ and $87 \mathrm{III}$, together with the history of the specific kinetic energy imparted to the water by the wind (impulse $=\mathrm{m}^{2} \mathrm{~s}^{-1}$ ) in 6 -hour time periods. A northward impulse of $2.5 \mathrm{~m}^{2} \mathrm{~s}^{-1}$ for 30 hours is required to raise the thermocline to the surface.

abundance in relation to continued relaxation of the wind after a strong event. Experiment 8711 in midJuly developed initially as anticipated, with increasing winds after a period of low winds. However, winds relaxed on the third day (10 July), resulting in measurements at the beginning, middle, and end of a brief episode of upwelling favorable winds. Experiment 87III developed as anticipated, with weakening winds after an episode of upwelling favorable winds. Experiment 881 developed as anticipated, with upwelling favorable winds strengthening from the south. During this experiment the cross-shore wind component switched from strongly downwelling favorable to strongly upwelling favorable. Experiment 881I developed as anticipated, with strengthening of upwelling favorable winds. Experiment 89l developed as anticipated, as upwelling favorable winds weakened prior to the experiment, then increased during the experiment. The winds prior to the experiment were not energetic enough, in theory, to have raised the thermocline to the surface. Experiment 89ll developed as expected, with strengthening of upwelling favorable winds after a period of downwelling favorable winds.
The predicted response of the ocean to wind stress was tabulated in four categories (present, absent, relaxing, or spinning up) according to the observed decrease or increase in wind strength prior to and during the experiment. Both longshore and cross-shore histories were calculated for the Avalon Channel, with a coast running $20^{\circ}$ west of north. Table 1 shows the predicted response of the ocean in four categories.

SST profiles for 1987 showed cooler water near the coast at predicted times and at the predicted lateral extent of the first internal Rossby radius. Along transect $\mathrm{C}$ cold water occurred within $4 \mathrm{~km}$ of the coast at the beginning of experiment 871 , but not on the next day. A similar result was observed along transect $B_{e}$ (Schneider, 1989). During experiment $87 \mathrm{II}$ no cold water was observed near the coast at the outset on either transect $\mathrm{B}$ or $\mathrm{C}$, as predicted. Cooler water was observed within 3 and 6 $\mathrm{km}$ of the coast along transect $\mathrm{B}$ on the two subsequent days (Table 1). Measurements during the second experiment showed considerable smallscale horizontal gradients, due likely to the shallow depth of the thermistor during this experiment 
TABLE 1. Upwelling status, observed lateral extent $\left(\mathrm{L}_{\mathrm{R}}\right)$ of cold water at sea surface, and observed number $(\mathrm{N})$ of oneminute segments with positive $50 \mathrm{kHz}$ scores according to criterion 1 along transects $\mathrm{B}_{\mathrm{e}}, \mathrm{B}_{\mathrm{w}}$ and $\mathrm{C}$. Upwelling status ( $P=$ present, $A=$ absent, $S=$ spinning up, $R=$ relaxing) predicted from change in longshore (Lshore) and cross-shore (Xshore) wind strength, $L_{R}=0$ indicates no lateral gradient in SST at scale $>1 \mathrm{~km} .{ }^{*}$ indicates video record made with underwater camera. Blank = no data.

\begin{tabular}{|c|c|c|c|c|c|c|c|c|c|}
\hline \multirow[b]{2}{*}{ Experiment } & \multirow[b]{2}{*}{ Date } & \multicolumn{2}{|c|}{ Wind } & \multicolumn{3}{|c|}{$\mathrm{LR}(\mathrm{km})$} & \multicolumn{3}{|c|}{$\mathrm{N}$} \\
\hline & & Lshore & Xshore & $\overline{B_{e}}$ & $\mathrm{~B}_{\mathrm{w}}$ & $\mathrm{C}$ & $\overline{B_{e}}$ & $\mathrm{~B}_{\mathrm{w}}$ & $\mathrm{C}$ \\
\hline 871 & $\begin{array}{l}2 \text { July } \\
3 \\
4\end{array}$ & $\begin{array}{l}P \\
R \\
A / S\end{array}$ & $\begin{array}{l}P \\
R \\
A / S\end{array}$ & $\begin{array}{l}6 \\
0\end{array}$ & & $\begin{array}{l}4 \\
0\end{array}$ & $\begin{array}{r}35 \\
45 \\
6\end{array}$ & & $\begin{array}{r}18 \\
56 \\
6\end{array}$ \\
\hline 8711 & $\begin{array}{r}9 \\
10 \\
11\end{array}$ & $\begin{array}{l}A \\
S \\
R\end{array}$ & $\begin{array}{l}A \\
S \\
R\end{array}$ & $\begin{array}{l}0 \\
3 \\
6\end{array}$ & & 0 & $\begin{array}{r}12 \\
22 \\
1\end{array}$ & & $\begin{array}{r}14 \\
18 \\
5\end{array}$ \\
\hline $87 \mid I I$ & $\begin{array}{l}28 \\
29 \\
30\end{array}$ & $\begin{array}{l}P \\
R \\
R\end{array}$ & $\begin{array}{l}A \\
R \\
R\end{array}$ & $\begin{array}{l}6 \\
0\end{array}$ & & $\begin{array}{l}4 \\
6 \\
0\end{array}$ & $\begin{array}{l}1 \\
4 \\
8\end{array}$ & & $\begin{array}{l}1 \\
0 \\
7\end{array}$ \\
\hline 881 & $\begin{array}{l}27 \text { June } \\
28 \\
29\end{array}$ & $\begin{array}{l}A \\
S \\
S\end{array}$ & $\begin{array}{l}A \\
A \\
S\end{array}$ & $\begin{array}{r}0 \\
0 \\
12\end{array}$ & $\begin{array}{l}0 \\
0 \\
8\end{array}$ & & $\begin{array}{l}15 \\
76 \\
75\end{array}$ & $\begin{array}{l}26 \\
80 \\
80\end{array}$ & \\
\hline 8811 & $\begin{array}{l}12 \text { July } \\
13\end{array}$ & $\begin{array}{l}A \\
S\end{array}$ & $\begin{array}{l}A \\
S\end{array}$ & $\begin{array}{l}0 \\
6\end{array}$ & 0 & & & & $2^{*}$ \\
\hline 891 & $\begin{array}{l}28 \text { June } \\
29 \\
30\end{array}$ & $\begin{array}{l}A \\
S \\
R\end{array}$ & $\begin{array}{l}A \\
S \\
S\end{array}$ & $\begin{array}{l}0 \\
5 \\
5\end{array}$ & $\begin{array}{l}0 \\
4 \\
0\end{array}$ & & $\begin{array}{r}15 \\
0 \\
6\end{array}$ & $\begin{array}{r}11 \\
0 \\
2\end{array}$ & \\
\hline 8911 & $\begin{array}{l}4 \text { July } \\
5 \\
6 \\
9\end{array}$ & $\begin{array}{l}A \\
S \\
S \\
R / A\end{array}$ & $\begin{array}{l}A \\
S \\
S \\
R / A\end{array}$ & 0 & & 4 & $\begin{array}{l}1 \\
4\end{array}$ & & $\begin{array}{r}6 \\
10\end{array}$ \\
\hline
\end{tabular}

(ca $30 \mathrm{~cm}$ ) compared to the first experiment (ca 1.5 $\mathrm{m}$ ). During experiment $87 \mathrm{II}$ cooler water occurred near the surface within $6 \mathrm{~km}$ (transect B) and $4 \mathrm{~km}$ (transect $\mathrm{C}$ ) of the coast, as predicted. Cool water was observed near the coast on the following day, contrary to expectation. No thermal gradient occurred along either transect $\mathrm{B}$ or $\mathrm{C}$ on the third day, as expected.

Table 1 summarizes the results of 30 tests of the first hypothesis, i.e. of wind-driven water mass replacement occurs at the spatial scale predicted by the balance between buoyant and Coriolis force. Only one case (persistence of cold water near the coast on 29 July 87) was inconsistent with the upwelling hypothesis. The probability of 29 or more positive results out of 30 cases, assuming equal chance of a negative or positive result is less than $10^{-4}$, based on a binomial distribution. In only two cases did the lateral extent of cooler water differ greatly from the first internal Rossby radius, calculated as $5 \mathrm{~km}$ (Csanady, 1982, Eq. 3.97). The probability of 28 or more positive results out of 30 is less than $10^{-4}$, assuming an equal chance of positive and negative results.

\section{Gradients in capelin abundance perpendicular to the coast}

In general, scores according to Criterion 1 showed similar temporal trends on adjacent transects $\left(B_{e}\right.$ and $\left.C\right)$ or repeated traverses $\left(B_{e}\right.$ and $B_{w}$ ) of the same transect (Table 1). Frequency of positive scores according to Criterion 2 (Table 2) differed considerably from the frequency according levels of Criterion 1 (Table 1). But while the number of Criterion 2 scores was lower, the pattern of distribution among transects was similar to that for Criterion 1 scores (Table 1, Table 2).

Capelin were present more frequently within the Rossby radius than beyond along transects $B_{e} B_{w}$ and $\mathrm{C}$ (Table 2). Positive differences (more observations within one Rossby radius than beyond) occurred more frequently than zero or negative differences; there were 13 positive differences out of the 15 cases having more than one count per transect (Table 3). The binomial probability of this outcome is $p=0.0037$, assuming equal chance of positive and negative differences. To control for the effects of local or smaller scale spatial gradients, spectral techniques were used to identify those cases where 
TABLE 2. Number of 1-minute segments with positive $50 \mathrm{kHz}$ scores (criterion 2) along transects. In = within one Rossby radius of the coast; Out = beyond one Rossby radius from the coast. Blank = no data. ${ }^{*}$ Indicates video record made with underwater camera.

\begin{tabular}{|c|c|c|c|c|c|c|c|c|c|c|c|}
\hline \multirow[b]{2}{*}{ Experiment } & \multirow[b]{2}{*}{ Date } & \multirow[b]{2}{*}{$A_{e}$} & \multicolumn{2}{|c|}{$B_{e}$} & \multicolumn{2}{|c|}{$B_{w}$} & \multicolumn{2}{|c|}{ C } & \multirow[b]{2}{*}{ D } & \multirow[b]{2}{*}{$\mathrm{E}$} & \multirow[b]{2}{*}{$A_{w}$} \\
\hline & & & In & Out & In & Out & In & Out & & & \\
\hline \multirow[t]{3}{*}{871} & 2 July & 16 & 3 & 11 & & & 3 & 0 & 9 & 5 & \\
\hline & & 5 & 22 & 10 & & & 22 & 13 & 10 & 3 & \\
\hline & 4 & 0 & 0 & 1 & 0 & 1 & & & & & 0 \\
\hline \multirow[t]{3}{*}{$87 \|$} & 9 & 0 & 0 & 0 & & & 0 & 1 & 5 & 0 & \\
\hline & 10 & 0 & 1 & 0 & & & 5 & 0 & 11 & 10 & \\
\hline & 11 & 0 & 0 & 0 & & & 2 & 0 & 1 & 0 & \\
\hline \multirow[t]{3}{*}{$87 \mid I I$} & 28 & 0 & 0 & 0 & & & 0 & 0 & 0 & 0 & \\
\hline & 29 & 0 & 0 & 0 & & & 0 & 0 & 3 & 0 & \\
\hline & 30 & 0 & 0 & 0 & & & 0 & 0 & 0 & 0 & \\
\hline \multirow[t]{2}{*}{881} & $\begin{array}{l}27 \text { June } \\
28\end{array}$ & 1 & 3 & 0 & 0 & 0 & & & & & 0 \\
\hline & 29 & 1 & 0 & 0 & 0 & 0 & & & & & 1 \\
\hline \multirow[t]{2}{*}{8811} & 12 July & 1 & 4 & 0 & & & $0^{*}$ & $0^{*}$ & $0^{*}$ & $0^{*}$ & \\
\hline & 13 & 1 & 0 & 0 & 0 & 0 & & & & & 0 \\
\hline \multirow[t]{3}{*}{891} & 28 June & 0 & 11 & 0 & 6 & 0 & & & & & 4 \\
\hline & 29 & 3 & 2 & 0 & 1 & 0 & & & & & 1 \\
\hline & 30 & 0 & 3 & 0 & 0 & 0 & & & & & 0 \\
\hline \multirow[t]{3}{*}{8911} & 4 July & 0 & 0 & 0 & & & 1 & 2 & 12 & 0 & \\
\hline & & 0 & 1 & 0 & & & 2 & 0 & 4 & 0 & \\
\hline & 6 & 2 & 0 & 0 & & & 4 & 0 & 13 & 0 & \\
\hline
\end{tabular}

TABLE 3. Conformity to Hypothesis 2 along transects B and C. Conformity marked Yes if spectral density of criterion 1 scores at low measurement frequencies $\left(V_{D<0.5 / \mathrm{km}}\right)$ exceeded spectral density at higher frequencies. Conformity marked Yes if number of criterion 2 scores within one Rossby radius of coast $\left(\mathrm{N}_{\mathrm{in}}\right)$ exceeded number of scores beyond one radius ( $\left.\mathrm{N}_{\text {out }}\right)$.

\begin{tabular}{|c|c|c|c|c|c|c|c|c|}
\hline \multirow[b]{2}{*}{ Experiment } & \multirow{2}{*}{\multicolumn{2}{|c|}{ Date }} & \multicolumn{3}{|c|}{$V_{D<.5 / \mathrm{km}}>V_{D>.5 / \mathrm{km}} ?$} & \multicolumn{3}{|c|}{$N_{\text {in }}>N_{\text {out }} ?$} \\
\hline & & & $\mathrm{B}_{\mathrm{e}}$ & $B_{w}$ & $\mathrm{C}$ & $\mathrm{B}_{\mathrm{e}}$ & $\mathrm{B}_{\mathrm{w}}$ & C \\
\hline $87 \mid$ & $\begin{array}{l}2 \\
3 \\
4\end{array}$ & July & $\begin{array}{l}\text { Yes } \\
\text { Yes } \\
\text { No }\end{array}$ & & $\begin{array}{l}\text { Yes } \\
\text { Yes } \\
\text { No }\end{array}$ & $\begin{array}{l}\text { No } \\
\text { Yes }\end{array}$ & & $\begin{array}{l}\text { Yes } \\
\text { Yes }\end{array}$ \\
\hline 8711 & $\begin{array}{r}9 \\
10 \\
11\end{array}$ & & $\begin{array}{l}\text { Yes } \\
\text { Yes }\end{array}$ & & $\begin{array}{l}\text { No } \\
\text { Yes } \\
\text { Yes }\end{array}$ & & & $\begin{array}{l}\text { Yes } \\
\text { Yes }\end{array}$ \\
\hline $87 I I 1$ & $\begin{array}{l}28 \\
29 \\
30\end{array}$ & & & & & & & \\
\hline 881 & $\begin{array}{l}27 \\
28 \\
29\end{array}$ & June & $\begin{array}{l}\text { Yes } \\
\text { No } \\
\text { Yes }\end{array}$ & $\begin{array}{l}\text { No } \\
\text { No }\end{array}$ & & Yes & & \\
\hline 8811 & $\begin{array}{l}12 \\
13\end{array}$ & July & $\begin{array}{l}\text { Yes } \\
\text { Yes }\end{array}$ & & & Yes & & \\
\hline 891 & $\begin{array}{l}28 \\
29 \\
30\end{array}$ & June & $\begin{array}{l}\text { Yes } \\
\text { Yes }\end{array}$ & Yes & & $\begin{array}{l}\text { Yes } \\
\text { Yes } \\
\text { Yes }\end{array}$ & Yes & \\
\hline 8911 & & July & No & & $\begin{array}{l}\text { No } \\
\text { Yes } \\
\text { Yes }\end{array}$ & & & $\begin{array}{l}\text { No } \\
\text { Yes } \\
\text { Yes }\end{array}$ \\
\hline
\end{tabular}


large scale variance exceeded small scale variance. Large scale variance exceeded small scale variance $\left(V_{D<.5 / \mathrm{km}}>V_{D>.5 / \mathrm{km}}\right)$ in all 13 instances where the gradient in abundance was positive at the scale of the Rossby radius (i.e., $\mathrm{N}_{\text {in }}>\mathrm{N}_{\text {out }}$ ). Hence the observed gradient at the scale of the Rossby radius was not due to smaller scale gradients.

This pattern of habitat affinity was not, however, associated with upwelling events as indicated by changes in wind or by appearance of cold upwelled water near the coast. Classification of the 13 positive gradients in Table 3, relative to upwelling status predicted by winds (Table 1) resulted in 9 positive gradients in the presence of upwelling favorable winds, 4 positive gradients in the absence of upwelling winds. Only positive gradients were scored in a one-way classification because two-way classification resulted in expected cell values less than two, which preclude calculation of $\mathrm{p}$-values from a $\chi^{2}$ distribution. Positive gradients were not associated with the presence of upwelling winds (9 successes out of 13 cases, $p=0.13$ from binomial distribution with parameter $=0.5)$. Positive gradients in abundance occurred in the presence ( 3 cases) and absence ( 7 cases) of upwelled water $(L R>0$ in Table 1).

\section{Change in coarse-scale variability}

Generation and decay of low-frequency spatial variability at the spatial scale of coastal upwelling was tested by plotting spectral densities for each transect on successive days. Three (sometimes two) successive dates were then ranked as having high, medium or low spectral density at wavelengths less than $2 \mathrm{~km}$. Table 4 shows the outcome of the rankings, with listing of whether the rankings conform to or deviate from Hypothesis 3 , as judged relative to upwelling status predicted from winds (Table 1). Rankings changed in the expected directions in 8 of 12 cases, but this was not significant assuming equal chance of successful or unsuccessful prediction ( $p=0.19$, binomial distribution with $n=12, \hat{p}=0.5)$. Relative to the appearance of upwelled water (Table 1), rankings changed in the predicted direction in only 2 of 7 cases (Table 4). Hypothesis 3 was not supported by change in spectral density relative to either upwelling favorable winds or to presence of upwelled water.

A similar analysis of Hypothesis 3 was carried out for differences in counts based on Criterion 2. Aggregation (as measured by frequency of positive counts within the Rossby radius less the frequency of counts beyond the Rossby radius) changed in the direction expected from upwelling favorable winds (Table 1) in 6 of 13 cases (Table 5). Aggregation changed in the direction expected from the appearance of upwelled water (Table 1) in only 1 of
8 cases. This last result amounts to an improbable number of failures ( $p=0.035$, binomial distribution, $n=9, \hat{p}=0.5)$. Hypothesis 3 , that of change in variability in presence or absence of capelin as a function of intermittent upwelling, was not supported by analysis of Criterion 1 or Criterion 2 counts.

\section{Discussion}

A variety of data collection and analytical techniques were used in this study, so some comment is in order. Positive traces within $12 \mathrm{~km}$ of the coast during late June and early July were considered to be capelin, consistent with previous studies at this site (Schneider and Piatt, 1986; Schneider, 1989; Piatt, 1990). The evidence in these studies was (1) that other schooling nekton (e.g. squid or herring) do not appear in the area during this period; (2) capelin are the primary item in the diet of seabirds feeding over traces interpreted as capelin; (3) similar traces do not appear in the area after the capelin spawning season. The towed camera showed that traces interpreted as capelin did consist of small schooling fish. Capelin (and only capelin) were observed in the bills of alcids feeding above schooling fish identified as continuous dark traces in the echosounder.

Two methods were used to digitize the acoustic record - all traces in blocks $10 \mathrm{~m}$ deep by ca $200 \mathrm{~m}$ long (Criterion 1), and contiguous traces extending vertically, often with slight lateral twisting or diagonal displacement (Criterion 2). The two methods used in the present study gave consistent results. The patterns of abundance among transects were the same (on a rank basis) for both techniques (Table 1, Table 2). Criterion 1 may introduce noise into the data, based on limited camera work in the study area in 1988. Introduction of noise would not affect conclusions based on detection of a significant difference, i.e. no affect on Type I error. Introduction of noise would affect conclusions based on failure to detect a difference, i.e. an increase in Type II error. Conclusions based on Criterion 2 were considered to be less affected by this source of decrease in sensitivity.

The data consisted of the number of locations with capelin present, rather than biomass estimates. Somewhat different results might have been obtained if biomass, rather than abundance, could have been measured. It would be indeed surprising, however, if there were strong changes in biomass without changes in the presence/absence of capelin, as measured in this study.

Two different techniques were used to analyze presence/absence data - spectral analysis of Criterion 1 counts, and subtracting Criterion 2 counts. Conclusions were based primarily on the latter. 
TABLE 4. Ranking of spectral density $V_{D<0.5 \mathrm{~km}}$ on 3 (sometimes 2) successive days within transects $B_{e}$, $B_{w}$, and C. Conformity of ranking to Hypothesis 3 marked Yes if ranking increased or decreased in the direction expected from change in wind or SST (Table 1).

\begin{tabular}{|c|c|c|c|c|c|c|c|c|c|c|}
\hline \multirow[b]{2}{*}{ Experiment } & \multirow[b]{2}{*}{ Date } & \multicolumn{3}{|c|}{ Ranking } & \multicolumn{3}{|c|}{ Wind } & \multicolumn{3}{|c|}{ SST } \\
\hline & & $\mathrm{B}_{\mathrm{e}}$ & $\mathrm{B}_{\mathrm{w}}$ & C & $\mathrm{B}_{\mathrm{e}}$ & $\mathrm{B}_{\mathrm{w}}$ & C & $\mathrm{B}_{\mathrm{e}}$ & $\mathrm{B}_{\mathrm{w}}$ & C \\
\hline 871 & $\begin{array}{l}2 \text { July } \\
3 \\
4\end{array}$ & $\begin{array}{l}\text { High } \\
\text { High } \\
\text { Low }\end{array}$ & & $\begin{array}{l}\text { High } \\
\text { Medium } \\
\text { Low }\end{array}$ & $\begin{array}{l}\text { No } \\
\text { Yes }\end{array}$ & & $\begin{array}{l}\text { Yes } \\
\text { Yes }\end{array}$ & No & & Yes \\
\hline 8711 & $\begin{array}{r}9 \\
10 \\
11\end{array}$ & $\begin{array}{l}\text { High } \\
\text { Low }\end{array}$ & & $\begin{array}{l}\text { Low } \\
\text { High } \\
\text { Low }\end{array}$ & No & & $\begin{array}{l}\text { Yes } \\
\text { Yes }\end{array}$ & No & & \\
\hline 87111 & $\begin{array}{l}28 \\
29 \\
30\end{array}$ & & & & & & & & & \\
\hline 881 & $\begin{array}{l}27 \text { June } \\
28 \\
29\end{array}$ & $\begin{array}{l}\text { High } \\
\text { Medium } \\
\text { Low }\end{array}$ & $\begin{array}{l}\text { High } \\
\text { Low } \\
\text { Low }\end{array}$ & & No & No & & No & No & \\
\hline 8811 & $\begin{array}{l}12 \text { July } \\
13\end{array}$ & $\begin{array}{l}\text { Low } \\
\text { High }\end{array}$ & & & Yes & & & Yes & & \\
\hline 891 & $\begin{array}{l}28 \text { June } \\
29 \\
30\end{array}$ & $\begin{array}{l}\text { High } \\
\text { Low }\end{array}$ & & & Yes & & & No & & \\
\hline 8911 & $\begin{array}{l}4 \text { July } \\
5 \\
6\end{array}$ & & & $\begin{array}{l}\text { Low } \\
\text { High } \\
\text { High }\end{array}$ & & Yes & & & & \\
\hline
\end{tabular}

TABLE 5. Conformity to Hypothesis 3, based on criterion 2 scores, along transects $\mathrm{B}_{\mathrm{e}}, \mathrm{B}_{\mathrm{w}}$, and $\mathrm{C}$. Conformity marked Yes if Diff ( $\left.\mathrm{N}_{\text {in }}-\mathrm{N}_{\text {out }}\right)$ increased or decreased in the direction expected from change in wind or SST (Table 1).

\begin{tabular}{|c|c|c|c|c|c|c|c|}
\hline \multirow[b]{2}{*}{ Experiment } & \multirow[b]{2}{*}{ Date } & \multicolumn{3}{|c|}{ Wind } & \multicolumn{3}{|c|}{ SST } \\
\hline & & $\mathrm{B}_{\mathrm{e}}$ & $\mathrm{B}_{\mathrm{w}}$ & $C$ & $\overline{B_{e}}$ & $\mathrm{~B}_{\mathrm{w}}$ & $\mathrm{C}$ \\
\hline \multirow[t]{3}{*}{871} & 2 July & & & & & & \\
\hline & 3 & No & & Yes & No & & Yes \\
\hline & 4 & Yes & & & & & \\
\hline \multirow[t]{3}{*}{8711} & 9 & & & & & & \\
\hline & 10 & & & Yes & & & \\
\hline & 11 & & & Yes & & & \\
\hline \multirow[t]{3}{*}{ 87III } & 28 & & & & & & \\
\hline & 29 & & & & & & \\
\hline & 30 & & & & & & \\
\hline \multirow[t]{3}{*}{881} & 27 June & & & & & & \\
\hline & 28 & & & & & & \\
\hline & 29 & No & & & No & No & \\
\hline \multirow[t]{2}{*}{8811} & 12 July & & & & & & \\
\hline & 13 & No & & & No & & \\
\hline \multirow[t]{3}{*}{891} & 28 June & & & & & & \\
\hline & 29 & No & No & & No & No & \\
\hline & 30 & No & No & & No & & \\
\hline \multirow[t]{3}{*}{8911} & 4 July & & & & & & \\
\hline & 5 & & & Yes & & & \\
\hline & 6 & & & Yes & & & \\
\hline
\end{tabular}


Spectral methods were used to identify those cases where larger scale variability exceed smaller scale variability.

The parametric methods developed for hypothesis testing in spectral analysis were inappropriate for the data, and were not used.

Patterns of habitat affinity observed in this study were consistent with those observed in prior work (1984-86) at this site (Piatt, 1990). The highest frequency of counts occurred over a ledge area near the coast (transect D), lower frequency of counts occurred in a sheltered bay or away from the coast (Table 2). The present study shows that patterns of variation along a transect perpendicular to the coastline (Schneider and Piatt, 1986) were repeatable on adjacent transects ( $B_{e}$ versus $C$ ) as well as being repeatable on sequential traverses of the same transect ( $B_{e}$ versus $B_{w}$, Tables 1 and 2$)$. The present study extends these results by showing that spatial variability that occurs at this site occurs at the scale of the first internal Rossby radius.

The mechanism previously proposed to explain this variability is response to thermal gradients due to coastal upwelling (Schneider and Piatt, 1986). The present analysis showed that a single, strong event generated spatial variance in capelin abundance in early July, 1987, but that on the average, upwelling events do not generate variance in abundance. This indicates that capelin respond to extremely strong thermal events, but respond little or not at all to typical events. A similar situation, where biological responses to strong physical events are recorded in the literature, but the average response is weak or non-existent, applies to the association of marine birds with fronts, or water mass boundaries (Schneider et al., 1987). This in turn suggests the generalization that reports of association of large, highly mobile marine organisms with physical features such as fronts, eddies, or thermal barriers are due to responses to extreme conditions, rather than due to typical responses to these physical features. This hypothesis, that association of mobile marine organisms with water mass structure is episodic and atypical, can only be tested with repeated observational experiments.

\section{Acknowledgements}

Thanks to Paul Normore and John Way for field assistance and data reduction, and to C.C.E. Hopkins, W. Leggett and an anonymous reviewer for critical comments. This study was funded by the Natural Sciences and Engineering Research Council (Ottawa).

\section{References}

BUZDALIN, Y.I, and V.V. BURMAKIN. 1976. O svyazi mezhdu temperaturoi poverxhnosti morya i plotnostyu skoplenii moivi v raione Nyufaundlenda. Tr. PINRO, Murmansk, 37: 57-60.

CSANADY, G. 1982. Circulation in the Coastal Ocean. Dordrecht: Reidel, $279 \mathrm{p}$.

DIXON, W.J. 1983. BMDP Statistical Software. Berkeley: University of California Press, $734 \mathrm{p}$.

PIATT, J.F. 1987. Behavioural ecology of Common Murre and Atlantic Puffin predation on capelin: implications for population biology. Ph.D. thesis, Memorial University of Newfoundland, St. John's, $311 \mathrm{p}$.

PIATT, J.F. 1990. The aggregative response of Common Murres and Atlantic Puffins to schools of capelin. Stud. Avian Biol., 14: 36-51.

PIATT, J.F., and D.A. METHVEN. 1986. Marine Food Webs: Behavioural Interactions at Witless Bay, Newfoundland. Report to Department of Supply and Services Canada, St. John's, Newfoundland, 308 p.

SCHNEIDER, D.C. 1989. Identifying the spatial scale of density-dependent interaction of predators with schooling fish in the southern Labrador Current. J. Fish Biol., 35: 109-115.

SCHNEIDER, D.C., N.M. HARRISON, AND G.L. HUNT. 1987. Variation in the occurrence of marine birds at fronts in the Bering Sea. Estuar. Coast. Shelf Sci., 25: 135-141.

SCHNEIDER, D.C., and D.A. METHVEN. 1988. Response of capelin to wind-induced thermal events in the southern Labrador Current. J. Mar. Sci., 46: 105-118.

SCHNEIDER, D.C., and J.F. PIATT. 1986. Scale-dependent correlation of seabirds with schooling fish in a coastal ecosystem. Mar. Ecol. Prog. Ser., 32: 237246.

SLEGGS, G.F. 1933. Observations upon the economic biology of the capelin (Mallotus villosus O.F. Müller). Reports Nfld. Fishery Research Lab., 1: 1-66.

TEMPLEMAN W. 1948. The life history of the capelin (Mallotus villosus O.F. Müller) in Newfoundland waters. Res. Bull. Dept. Natural Resources, Nfld., 17: $1-151$. 
